\title{
DECISION MAKING ON E-ASSESSMENT CRITERIA IN RUBRICS
}

\begin{abstract}
This paper describes the way in which rubrics and the Analytic Hierarchy Process (AHP) can be used in a study program or course in order to assess fulfillment of learning outcomes (LOs) when students are involved in problem solving. In the process of determining weights of e-assessment criteria in rubrics, we have used the AHP and group decision making. The case study of problem solving exercise in the course Discrete Mathematics with Graph Theory (DMGT) is presented in the paper.
\end{abstract}

Keywords:e-assessment criteria, AHP, rubrics, learning outcomes, group decision making

\section{Introduction}

It is widely accepted that assessment should be based on well defined assessment criteria. When learning outcomes and assessment criteria are identified, they can be implemented by rubrics in a virtual environment. Well defined rubrics can communicate to students what is asked from them and support enhancement of their critical reasoning skills. Rubrics are especially useful when more teachers are assessing the assignment, in a case of a problem-based learning, group work and/or peer assessment. In process of building comprehensive rubrics there are two essential processes: a) formulating e-assessment criteria connected to defined LOs, b) determining weights of e-assessment criteria that take into account different perspectives.

\section{Objectives}

Objectives of this paper are: a) to show how rubrics can be implemented when a complex learning task is required and more teachers are assessing the assignment, $b$ ) to show how to use the AHP in determining weights of assessment criteria in a rubric.

\section{Methodology}

Let us describe the way in which we used rubrics in DMGT course in order to assure the fulfilment of the learning outcome (LO) concerning mathematical modelling and problem solving. DMGT is taught at master level of study programs Information Systems and Software Engineering as a blended learning course. Table 1 shows constructive alignment of the LO with teaching, learning and assessment.

Table 1. Constructive alignment of one LO on the course DMGT

\begin{tabular}{|l|l|l|l|l|}
\hline Study program LO & $\begin{array}{l}\text { Course specific } \\
\text { LO }\end{array}$ & $\begin{array}{l}\text { Teaching and } \\
\text { learning method }\end{array}$ & Assessment method & ECTS credits \\
\hline $\begin{array}{l}\text { Apply mathematical } \\
\text { methods appropriate } \\
\text { for solving problems } \\
\text { in the field } \\
\text { of information } \\
\text { systems }\end{array}$ & $\begin{array}{l}\text { Solve real world } \\
\text { problems in ICT } \\
\text { with methods } \\
\text { from graph theory } \\
\text { and discrete } \\
\text { maths }\end{array}$ & $\begin{array}{l}\text { Students work in } \\
\text { teams of three on } \\
\text { posing and solving } \\
\text { authentic problems - } \\
\text { online work }\end{array}$ & $\begin{array}{l}\text { Teacher assessment } \\
\text { and partially peer } \\
\text { assessment- problem } \\
\text { posing and problem } \\
\text { solving based on } \\
\text { criteria and rubrics }\end{array}$ & $\begin{array}{l}40 \text { hours }=1.5 \\
\text { ECTS (approx. } \\
20 \% \text { of the } \\
\text { course 7 ECTS) }\end{array}$ \\
\hline
\end{tabular}

Real problem posing and solving contributes to $20 \%$ of the overall course grade (student workload of 30-40 hours). From the outset it is important to recognize the assessment criteria and then to attach grades and levels describing certain grading to each criteria. In 
our case of problem posing and solving we first have to weight relative significance of these two phases having in mind the intended learning outcomes. It was decided to introduce the ratio $2: 3$ between phases I and II i.e. 8 points to criteria for the problem posing phase and 12 to the problem solving phase. It was justified by group decision making using the AHP (Decision Lens) and the decision makers were: one professor, two research assistants and one former student. Their judgements were equally weighed during the decision making, exercise was performed anonymously and afterwards the judgements were aggregated. In the next step it was essential to recognize sub-criteria that would appear in the scoring rubrics. After defining sub-criteria (brainstorming and consensus) the relative importance of different sub-criteria are determined again by group DM using the AHP (Figure 1). The results were used in scoring rubrics (Appendices).

\section{Model Analysis}

Figure 1.Weighted tree-view for criteria and sub-criteria in rubrics-results of group DM

Discrete mathematics with graph theory - weights
of criteria
\begin{tabular}{|c|l|l|}
\hline 0.373 & Problem posing \\
\hline 0.058 & Problem relevance \\
\hline 0.137 & Problem description \\
\hline 0.177 & Characteristics of solutions \\
\hline 0.627 & Problem solving \\
\hline 0.107 & Linking given problems with theory of DMGT \\
\hline 0.145 & Strategy of solving \\
\hline 0.153 & Characteristics of the solution \\
\hline 0.147 & Implementation of solution \\
\hline 0.075 & Written and oral presentation \\
\hline
\end{tabular}

\section{Conclusions}

When rubrics with well defined and weighted criteria are used in virtual environment, assessment is transparent, learning-oriented and consistent. Students become aware of demand for solving non-structured real-world problems and appreciate mathematical modelling as a useful skill.

\section{Key References}

Divjak, B. (2015). Assessment of complex, non-structured and mathematical problems, IMA International Conference on Barriers and Enablers to Learning Maths, Glasgow Saaty, T.L., \& Peniwati, K. (2007). Group decision-making: Drawing out and reconciling differences. Pittsburgh, PA: RWS Publications

\section{Appendices}

Figure 2. Scoring rubrics for sub-criteria Problem relevance and Problem description

\begin{tabular}{|c|c|c|c|c|c|}
\hline \multirow[t]{2}{*}{ Criterion } & \multicolumn{5}{|c|}{ Level of achievement } \\
\hline & Poor $(0)$ & Acceptable & Good & Excellent & $\mathrm{P}$ \\
\hline \multicolumn{6}{|c|}{ Phase I-Problem posing } \\
\hline Problem relevance & $\begin{array}{l}\text { Problem is } \\
\text { copied or not } \\
\text { relevant. }\end{array}$ & $\begin{array}{l}\text { Problem is } \\
\text { standard for } \\
\text { DMGT. (1) }\end{array}$ & $\begin{array}{l}\text { Problem is interesting } \\
\text { and connected with } \\
\text { DMGT.(1.5) }\end{array}$ & $\begin{array}{l}\text { Problem is challenging \& } \\
\text { interesting and can be } \\
\text { connected to DMGT. (2) }\end{array}$ & 2 \\
\hline Problem description & $\begin{array}{l}\text { Problem is not } \\
\text { clearly described } \\
\text { or it is not a } \\
\text { problem. }\end{array}$ & $\begin{array}{l}\text { Problem is } \\
\text { described but } \\
\text { without additional } \\
\text { data, links or real } \\
\text { context. (1) }\end{array}$ & $\begin{array}{l}\text { Problem is described } \\
\text { clearly but there is no } \\
\text { important (relevant) } \\
\text { real context. (2) }\end{array}$ & $\begin{array}{l}\text { Problem is described in } \\
\text { clear and interesting way } \\
\text { with relevant real context. } \\
\text { (3) }\end{array}$ & 3 \\
\hline
\end{tabular}

International Symposium on the 2 